\title{
Feeding rate and sediment reworking by the holothuroid Holothuria tubulosa (Echinodermata) in a Mediterranean seagrass bed off Ischia Island, Italy
}

\author{
Pierre Coulon ${ }^{1}$, Michel Jangoux ${ }^{1,2}$ \\ ${ }^{1}$ Laboratoire de Biologie marine (CP160/15), Université Libre de Bruxelles, 50 av. F. D. Roosevelt, B-1050 Bruxelles, Belgium \\ ${ }^{2}$ Laboratoire de Biologie marine, Université de Mons-Hainaut, 19 av. Maistriau, B-7000 Mons, Belgium
}

\begin{abstract}
Values of Holothuria tubulosa feeding rate range over 1 order of magnitude (from 0.049 to $0.489 \mathrm{~g} \mathrm{dw}$ sediment $\mathrm{h}^{-1}$ ) depending on individuals' size and environmental conditions. Feeding rate is correlated with season (increase of water temperature leads to increase of feeding rate) and with the nycthemeral cycle (individuals being more active at night). Feeding rate data allowed the yearly amount of sediment reworked by the $H$. tubulosa population of the Lacco Ameno seagrass bed to be calculated. Obtained values differ in the lower and upper part of the meadow (5.9 and $12.9 \mathrm{~kg} \mathrm{dw}$ sediment $\mathrm{m}^{-2} \mathrm{yr}^{-1}$ respectively), according to local differences in population structure, light and temperature regime.
\end{abstract}

Aspidochirote holothuroids are prominent benthic representatives in many littoral ecosystems (Harrold \& Pearse 1987, Birkeland 1988). They are large-sized deposit-feeding echinoderms that ingest superficial sediment and feed on non-living detritus and associated microorganisms (Massin \& Jangoux 1976, Moriarty 1982, Birkeland 1988). Due to their feeding activity, holothuroids must have strong effects on the environment: they are active sediment reworkers that alter the bottom stability (Massin 1982), promote the return of nutritive elements to the water column (Rhoads \& Young 1971) and enhance the production of sedimentassociated bacteria (Amon \& Herdnl 1991). The common Mediterranean species Holothuria tubulosa inhabits Posidonia oceanica meadows where it often occurs in dense populations and represents a significant part of the macrozoobenthic biomass (Gustato et al. 1982, Bulteel et al. 1992a).

The purpose of this paper is to measure the feeding rates of Holothuria tubulosa at day and at night in sum- mer and winter, and to assess the amount of sediment reworked by the species over a 1 yr period.

Materials and methods. Individuals of Holothuria tubulosa Gmelin, 1788 were collected by SCUBA diving in the Posidonia oceanica meadow of Lacco Ameno (NNE part of Ischia Island, Italy) in July and December 1991. Because the $H$. tubulosa population of the Lacco Ameno has a well-marked size-related bathymetric distribution (Bulteel et al. 1992b), samplings were done at 2 different depths. Small individuals (body wall $\mathrm{dw}$ : $2.0 \pm 1.1 \mathrm{~g}$ ) were collected at $6 \mathrm{~m}$ deep in the upper part of the meadow: large individuals (body wall $\mathrm{dw}$ : $11.7 \pm 4.2 \mathrm{~g}$ ) were collected at $33 \mathrm{~m}$ deep in the lower part of the meadow. Specimens were brought into the laboratory and kept for $48 \mathrm{~h}$ in a large acclimatization tank before being transferred to experimental tanks (open circuit marine aquarium; water temperature: $25^{\circ} \mathrm{C}$ in July and $14{ }^{\circ} \mathrm{C}$ in December; salinity: $38 \%$ ). Both types of tank were lined with sediment originating from the same sampling site as the holothuroids. (The sediment of the experimental tanks had been previously stained with methylene blue according to the technique of De Ridder \& Jangoux 1985.)

To determine the mean feeding rate of Holothuria tubulosa, 8 sets of experiments were conducted using small or large individuals fed at day or night in summer (July) or winter (December). For each experimental set, 11 to 16 holothuroids were placed simultaneously in the corresponding experimental tank (starting time of the experiment), and 1 to 3 individuals were taken randomly at regular time intervals (every 30 or $60 \mathrm{~min}$ ) over a period of $8 \mathrm{~h}$ (maximal value of the gut transit time according to Massin \& Jangoux 1976). Individuals 
were then dissected and their body-wall and the gutcontained blue sediment were dried $\left(72 \mathrm{~h}\right.$ at $\left.70^{\circ} \mathrm{C}\right)$ and weighted.

For each set of experiments, the value of the corresponding feeding rate is given by the slope of the regression line calculated from the ratio between the dry weight of sediment ingested by a given holothuroid (i.e. the weight of blue sediment; $g \mathrm{dw}$ S) and the weight of its body-wall ( $g \mathrm{dw} \mathrm{H}$ ) according to time (h). Values of feeding rates are thus expressed in gram of sediment dry weight per gram of body-wall dry weight per hour ( $g \mathrm{dw} \mathrm{S} \mathrm{g} \mathrm{g}^{-1} \mathrm{dw} \mathrm{H} \mathrm{h}^{-1}$ ).

Results and discussion. Feeding rate: All investigated individuals started to feed in the course of the 15 min following their transfer from acclimatization to experimental tanks; the time of the transfer thus can be considered reliably as the starting time of each experiment. However, that Holothuria tubulosa is a continu-

Table 1. Holothuria tubulosa. Feeding rates according to size, period of the day and season (aquarium conditions)

\begin{tabular}{|c|c|c|c|}
\hline $\begin{array}{l}\text { Type of } \\
\text { experiment }\end{array}$ & $\begin{array}{l}\text { Feeding rate } \\
\left(\mathrm{gdwS} \mathrm{g}^{-1}\right. \\
\left.\mathrm{dw} \mathrm{H} \mathrm{h}^{-1}\right)^{\mathrm{a}}\end{array}$ & $\begin{array}{l}\text { Correlation } \\
\text { coefficient }\end{array}$ & $\begin{array}{l}\text { No. of } \\
\text { indivi- } \\
\text { duals }\end{array}$ \\
\hline \multicolumn{4}{|l|}{ Small individuals fed: } \\
\hline At day in summer & 0.285 & 0.733 & 14 \\
\hline At night in summer & 0.474 & 0.802 & 11 \\
\hline At day in winter & 0.050 & 0.765 & 15 \\
\hline At night in winter & 0.049 & 0.707 & 13 \\
\hline \multicolumn{4}{|l|}{ Large individuals fed: } \\
\hline At day in summer & 0.100 & 0.898 & 12 \\
\hline At night in summer & 0.489 & 0.828 & 14 \\
\hline At day in winter & 0.131 & 0.810 & 16 \\
\hline At night in winter & 0.108 & 0.879 & 16 \\
\hline \multicolumn{4}{|c|}{$\begin{array}{l}\text { "Calculated from the ratio between the dry weight of } \\
\text { ingested sediment ( } \mathrm{dw} \text { S) and the dry weight of individu- } \\
\text { als body wall }(\mathrm{d} w \mathrm{H})\end{array}$} \\
\hline
\end{tabular}

ous feeder (Massin \& Jangoux 1976) does not imply its feeding rate remains unchanged whatever the environmental conditions. Though highly different feeding rate values were obtained between our 8 sets of experiments, calculations of the corresponding correlation coefficients indicate a rather homogeneous feeding behaviour in each experimental set (Table 1). In order to demonstrate whether or not the differences that occur in the daily and seasonal feeding rates are significant, they were statistically compared 2 by 2 (parallelism tests: Dagnelie 1970). Results are presented in Table 2. They indicate that individuals in winter have no nycthemeral feeding rhythm while in summer such rhythm occurs for large individuals only (i.e. they are more active at night). The effect of season consists of a winter decrease of the feeding activity of all individuals. In small holothuroids, that decrease is due to an overall slackening of their feeding rates. In large holothuroids, it is due to the suppression of the summer nycthemeral feeding rhythm (in winter the feeding rates of large holothuroids are similar at day and night, and similar to their feeding rate at day in summer)

These results demonstrate that variation in light intensity and/or water temperature can affect Holothuria tubulosa feeding activity. These 2 environmental factors have different consequences according to whether individuals are small or large. This can be explained, however, providing we consider that the observed aquarium behaviour of holothuroids expresses their original in situ behaviour.

Indeed small individuals live in the upper and densest part of the meadow (ca 350 Posidonia oceanica shoots $\mathrm{m}^{-2}$; Pirc 1984) where they are rather cryptic, being located between $P$. oceanica rhizomes. They live in an almost permanent darkness and are mostly subject to temperature variations [from 25 to $14{ }^{\circ} \mathrm{C}$ (mean values) in summer and winter respectively]. These in-

Table 2. Holothuria tubulosa. Comparison of feeding rates under various environmental conditions

\begin{tabular}{|lcc|}
\hline Compared experimental sets & Corresponding feeding rates & Test of significance $^{\text {d }}$ \\
\hline Small holothuroids fed: & & NS \\
At day in summer versus at night in summer & 0.285 versus 0.474 & $\mathrm{NS}$ \\
At day in winter versus at night in winter & 0.050 versus 0.049 & $\mathrm{~S}$ \\
At day in summer versus at day in winter & 0.285 versus 0.050 & $\mathrm{~S}$ \\
At night in summer versus at night in winter & 0.474 versus 0.049 & $\mathrm{~S}$ \\
Large holothuroids fed: & & $\mathrm{NS}$ \\
At day in summer versus at night in summer & 0.100 versus 0.489 & $\mathrm{NS}$ \\
At day in winter versus at night in winter & 0.131 versus 0.108 & $\mathrm{~S}$ \\
At day in summer versus at day in winter & 0.100 versus 0.131 & \\
At night in summer versus at night in winter & 0.489 versus 0.108 & \\
aCalculated from parallelism test using Student table at $95 \%$ of degree of confidence; S and NS: significantly different or not \\
significantly different respectively
\end{tabular}


Table 3. Holothuria tubulosa. Amount of sediment reworked per year according to depth in the Lacco Ameno meadow

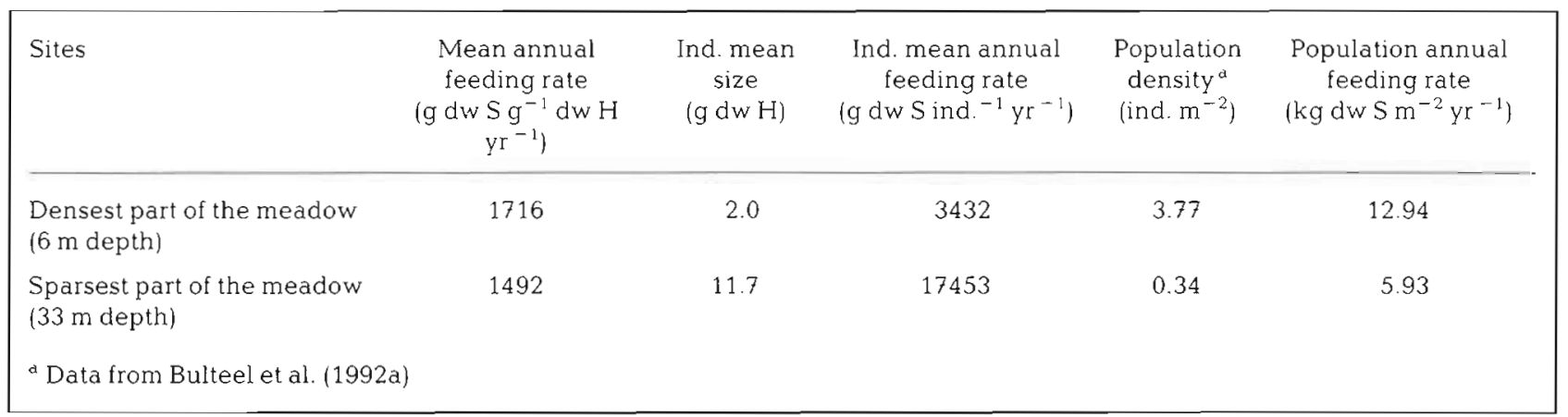

dividuals ingest more sediment in summer and never display a nycthemeral feeding rhythm.

Large individuals live on sandy areas in the lower and sparsest part of the meadow (less than 50 Posidonia oceanica shoots $\mathrm{m}^{-2}$; Pirc 1984) where they are located below the thermocline. They live in open area subject to light intensity variations, particularly in summer, and where temperature conditions are almost steady [from 18 to $14^{\circ} \mathrm{C}$ (mean values) in summer and winter respectively]. These individuals ingest similar amounts of sediment at day in winter and summer, and display a nycthemeral feeding rhythm in summer.

Thus temperature and light exert different pressures on the holothuroid individuals. Increase in water temperature produces an increase in feeding activity, while daily variations in light intensity lead to the appearance of a nycthemeral feeding rhythm (individuals being more active at night). This demonstrates that individuals of a given species living in the same area can display different feeding behaviours as a consequence of local environmental constraints.

The effects of temperature and light variations on holothuroid feeding activity are poorly documented in the literature. Authors generally consider holothuroids to exhibit a negative phototropism and to be more active at night (Crozier 1914, Bohnam \& Held 1963) though this appears not to be always true, particularly in the tropics (Hammond 1982). Some species, however, display a daily rhythm of activity that is said to be under the control of external light changes (Yamanouchi 1956, Crump 1965, Könnecker \& Keegan 1973). As for the effect of temperature, it was indirectly considered for temperate species entering a hibernation period (Haukson 1979, Smith \& Keegan 1985). According to Fish (1967), the winter fall of temperature would be the causal factor controlling the hibernation behaviour.

Sediment reworking: Sediment reworking by Holothuria tubulosa was assessed for mean-sized individuals originating from the 2 sampling stations (Table $3)$, viz. the $6 \mathrm{~m}$ depth station where mean weight of holothuroid body-wall is $2.0 \pm 1.1 \mathrm{~g} \mathrm{dw}$ and the $33 \mathrm{~m}$ depth station where mean weight of holothuroid bodywall is $11.7 \pm 4.2 \mathrm{~g} \mathrm{dw}$. The amount of sediment ingested per individual per year at each station was calculated from feeding rate values (Table 1) by subdividing arbitrarily the year into 6 summer months and 6 winter months with a day/night ratio of $16 \mathrm{~h} / 8 \mathrm{~h}$ and $8 \mathrm{~h} / 16 \mathrm{~h}$ respectively. The obtained values were then multiplied by the holothuroid density at each station (3.77 and 0.34 ind $\mathrm{m}^{-2}$ at 6 and $33 \mathrm{~m}$ depth respectively; see Bulteel et al. 1992a). This allowed an estimation that, in the studied meadow, the amount of sediment reworked by the $H$. tubulosa population is $12.9 \mathrm{~kg} \mathrm{dw} \mathrm{m} \mathrm{m}^{-2} \mathrm{yr}^{-1}$ at $6 \mathrm{~m}$ depth and $5.9 \mathrm{~kg} \mathrm{dw} \mathrm{m}^{-2}$ $\mathrm{yr}^{-1}$ at $33 \mathrm{~m}$ depth.

The only previous assessment of Holothuria tubulosa feeding pressure on the surrounding sediment was done by Francour (1989) from individuals inhabiting the seagrass bed of Port Cros (French Mediterranean coast). He reported sediment reworking values of about 18 and $8 \mathrm{~kg} \mathrm{dw} \mathrm{m}^{-2} \mathrm{yr}^{-1}$ in the shallow and deep parts of the meadow respectively. Francour's values, however - as those reported for other species (see e.g. Yamanouchi 1939, Haukson 1979, Yingst 1982) - rely on observations based on a few individuals investigated at a single season.

As Holothuria tubulosa only ingests the upper few mm of sediment and as the species is rather sedentary (Coulon pers. obs.), the values we obtained strongly suggest that a given sediment should pass several times a year through a holothuroid gut (a large individual may ingest up to $17.5 \mathrm{~kg}$ sediment dw per year). This emphasizes that holothuroids should play a major role in the detritus food chain of the Posidonia oceanica ecosystem.

Acknowledgements. We thank Dr L. Mazzella for prr facilities at the Laboratorio di Ecologia del Benthos (" Zoologica di Napoli). Research supported by the Euı. Community Commission (Environment Programmes EV4 V. 0139-B and STEP-0063-C). Contribution of the 'Centre Interuniversitaire de Biologie Marine' (CIBIM). 


\section{LITERATURE CITED}

Amon, R. M. W. Herndl, G. J. (1991). Deposit feeding and sediment: I. Interrelationship between Holothuria tubulosa (Holothuroidea, Echinodermata) and the sediment microbial community. P.S.Z.N. I: Mar. Ecol. 12: 163-174

Birkeland, C. (1988). The influence of echinoderms on coralreef communities. In: Jangoux, M., Lawrence, J. M. (eds.) Echinoderm studies, Vol. 3. Balkema, Rotterdam, p. 1-79

Bonham, K., Held, E. E. (1963). Ecological observations on the sea cucumbers Holothuria atra and $H$. leucospilota at Rongelap Atoll, Marshall Islands. Pacif. Sci. 17: 305-314

Bulteel, P., Coulon, P., Jangoux, M. (1992a). Densités de population des espèces dominantes d'échinodermes dans l'herbier de posidonies du Lacco Ameno (Ile d'Ischia, Italie): observations préliminaires. In: Scalera-Liaci, L., Canicatti, C. (eds.) Echinoderm research 1991 Balkema, Rotterdam, p. 181-183

Bulteel, P., Jangoux, M., Coulon, P. (1992b). Biometry, bathymetric distribution, and reproductive cycle of the holothuroid Holothuria tubulosa (Echinodermata) in Meditenanean seayrass ived's. P.S.Z.N. I: Mar. Ecoi. 13: 53-62

Crozier, W. J. (1.914). The orientation of a holothurian by light. Amer. J. Physiol. 36: 8-20

Crump, R. G. (1965). The diurnal activity of holothurians Malta '65 Symp. underw. Assoc. Malta, p. 43-45

Dagnnelie, r. (1970). Théorie et miéthodes statistiques, voi. 2. Editions J. Duculot, Gembloux

De Ridder, C., Jangoux, M. (1985). Origine des sédiments ingérés et durée du transit digestif chez l'oursin spatangide, Echinocardium cordatum (Pennant) (Echinodermata). Annls Inst. océanogr., Paris 61: 51-58

Francour, P. (1989). Le taux d'ingestion de sédiment par Holothuria polii et $H$. tubulosa (Echinodermata: Holothuroidea) dans un herbier à Posidonia oceanica. Posidonia Newsletter 2: 33-43

Fish, J. D. (1967). The biology of Cucumaria elongata (Echinodermata: Holothuroidea). J. mar. biol. Ass. U.K. 47: $129-143$

Gustato, G., Villari, A., Del Gaudio, S., Pedata, P. (1982). Ulteriori dati sulla distribuzione di Holothuria tubulosa, Holothuria polii e Holothuria stellati nel Golfo di Napoli. Boll. Soc. nat. Napoli 91: 1-14

Hammond, L. S. (1982). Patterns of feeding and activity in de- posit-feeding holothurians and echinoids (Echinodermata) from a shallow back-reef lagoon, Discovery Bay, Jamaica. Bull. mar. Sci. 32: 549-571

Harrold, C., Pearse, J. S. (1987). The ecological role of echinoderms in kelp forests. In: Jangoux, M., Lawrence, J. M. (eds.) Echinoderm studies, Vol. 2. Balkema, Rotterdam, p. $137-233$

Haukson, E. (1979). Feeding biology of Stichopus tremulus, a deposit-feeding holothurian. Sarsia 64: 155-160

Könnecker, G., Keegan, B. F. (1973). In situ behavioural studies on echinoderm aggregations. Part I. Pseudocucumis mixta. Helgoländer wiss. Meeresunters. 24: 157-162.

Massin, C. (1982). Effect of feeding on the environment: Holothuroidea. In: Jangoux, M., Lawrence, J. M. (eds.) Echinoderm nutrition. Balkema, Rotterdam, p. 493-4.96

Massin, C., Jangoux, M. (1976). Observations écologiques sur Holothuria tubulosa, $H$. poli et $H$. forskali (Echinodermata, Holothuroidea) et comportement alimentaire de H. tubulosa. Cah. Biol. mar. 17: 45-59

Moriarty, D. J. W. (1982). Feeding of Holothuria atra and Stichopus chloronotus on bacteria, organic carbon and organic nitrogen in sediments of the Great Barrier Reef. Aust. J. mar. fresinwat. Res. 33: 255-263

Pirc, H. (1984). Depth-adaptation in Posidonia oceanica (L.) Delile. In: Boudouresque, C.-F., Jeudy de Grissac, A., Olivier, J. (eds.) International workshop on Posidonia oceanica beds, Vol. 1. G.I.S. Posidonie Pub., Marseille, p. $22 \overrightarrow{7}-234$

Rhoads, D. C., Young, D. K. (1971). Animal-sediment relations in Cape Cod Bay, Massachusets II. Reworking by Molpadia oolitica (Holothuroidea). Mar. Biol. 11: 255-261

Smith, T. B., Keegan, B. F. (1985). Seasonal torpor in Neopendactyla mixta (Ostergren) (Holothuroidea: Dendrochirotida). In: Keegan, B. F., O'Connor, B. D. (eds.) Echinodermata. Balkema, Rotterdam, p. $459-464$

Yamanouchi, T (1939). Ecological and physiological studies on the holothurians in the coral reef of Palao Islands. Palao trop. biol. Stn Stud. 4: 603-636

Yamanouchi, T. (1956). The daily activity rhythms of the holothurians in the coral reef of Palao Islands. Publs Seto mar. biol. Lab. 5: 347-362

Yingst, J. Y. (1982). Factors influencing rates of sediment ingestion by Parastichopus parvimensis (Clark), an epibenthic deposit-feeding holothurian. Estuar. coast. Shelf Sci. 14: $119-134$

Manuscript first received: August 29, 1992

Revised version accepted: December 8, 1992 